\title{
Tricks and tactics used against troublesome travelers - Frontline staff's experiences from Swedish buses and trains
}

Nicklas Salomonson ${ }^{\mathrm{a}, *}$, Markus Fellesson ${ }^{\mathrm{b}}$

a School of Business and IT, University of Borås, Borås, SE-501 90, Sweden, email:

Nicklas.Salomonson@hb.se

${ }^{\text {b }}$ SAMOT research group, Karlstad University, Karlstad, SE-651 88, Sweden, email:

Markus.Fellesson@kau.se

This is a post-print of an article which has been published in the journal Research in Transportation Business and Management 10, 2014 by Elsevier Ltd. All rights reserved. (C) Nicklas Salomonson and Markus Fellesson. Available online at: https://www.sciencedirect.com/science/article/pii/S221053951400011X?via\%3Dihub

Use the following reference when citing the paper:

Salomonson, N., \& Fellesson, M. (2014). Tricks and tactics used against troublesome travelers-Frontline staff's experiences from Swedish buses and trains. Research in Transportation Business and Management, 10, 53-59. doi: 10.1016/j.rtbm.2014.04.002

\footnotetext{
* Corresponding author. Tel.: +46334354479.

E-mail address: Nicklas.Salomonson@hb.se
} 


\begin{abstract}
Public transport is facing escalating problems with passengers who behave badly by threatening and assaulting both staff and other passengers. Troublesome customers are known to affect employees' health and work motivation adversely. However, employees also form strategies for handling the incidents that arise. Developing successful ways of dealing with customer misbehavior, on both an operational and a strategic level, represents a key challenge facing the public transport sector. The aim of this article is to investigate the nature of such negative situations in public transport; in particular, highlighting the practical strategies that are used by public transport staff to handle these kinds of incidents. An interview study consisting of 23 in-depth interviews was conducted both with conductors on regional trains and bus drivers on local buses in Sweden. Several instances of customer misbehavior were described by the respondents, e.g. verbal abuse, threats, and even physical violence. These alarming incidents were dealt with by staff using a range of individual strategies aimed at averting or controlling misbehaving customers. Our study clearly demonstrates the importance of the employees' appearance and their interactional abilities, in addition to their use of the physical environment, when handling incidents that included misbehavior.
\end{abstract}

Keywords: Public transport, customer misbehavior, employee strategies 


\section{Tricks and tactics used against troublesome travelers - Frontline staff's experiences from Swedish buses and trains}

\section{Introduction}

Around the world, public transport organizations are embracing marketing as a strategic orientation in order to encourage innovation and renewal (Molander et al., 2012). One profound aspect of this trend is the change in how organizations are supposed to relate to their passengers, who are now to be considered customers. In marketing, this relationship is normally believed to be fundamentally positive in nature. As long as the organization listens to its customers and meets their needs - arguably the raison d'être of the organization (Levitt, 1960) - a win-win situation is created whereby both the organization and its customers can achieve their goals together. This concession to customer sovereignty holds true not only for the strategic orientation of the organization, when it comes to products and services, but also for day-to-day customer interactions, when the customer "becomes king" in the name of organizational success. However, this picture of harmony is not always valid.

We are ardent champions of the customer, but we do not believe in the maxim that "the customer is always right." Sometimes, the customer is wrong and unfairness often results. That the customer is sometimes wrong is a dirty little secret of marketing, known to many but rarely discussed in public - or in print. (Berry and Seiders, 2008, p. 29)

As indicated in the above quote, customer interactions are sometimes both disharmonious and unproductive. The aim of this article is to investigate the nature of such negative situations in public transport and, in particular, to highlight the practical strategies used by public transport staff when handling these kinds of incidents. While employee behavior which fosters positive service encounters is a well-researched area (cf. Bendapudi and Bendapudi, 2005; Bowen and Schneider, 1988; Jones et al., 1997; Korczynski et al., 2000; Pugh et al., 2002; Sturdy, 1998), far less is known about the resources needed to manage negative interactions with aberrant, or even threatening, customers (e.g. Bitner et al., 1994; Fullerton and Punj, 1993; Harris and Daunt, 2013; Harris and Reynolds, 2004; Reynolds and Harris, 2006). 
Understanding and preventing customer misbehavior in public transport is central to the strategic market-orientation of the sector. A public transport system where customers behave badly towards both each other and employees, and where threats and violence are common, risks becoming both expensive and unattractive (cf. Berry and Seiders, 2008; Grove and Fisk, 1997; Huang, 2008; Martin, 1996). Customer misbehavior also constitutes a severe work environment hazard (Grandey et al., 2004; SWEA, 2008; Yagil, 2008), being detrimental to the long-term motivation and well-being of employees (Ben-Zur and Yagil, 2005; Dormann and Zapf, 2004; Harris and Reynolds, 2003; Reynolds and Harris, 2006; van Dierendonck and Mevissen, 2002). Developing successful ways of dealing with customer misbehavior, on both an operational and a strategic level, thus represents a key challenge facing the public transport sector.

The paper continues with a brief introduction to the nature and prevalence of customer misbehavior. Next, our interview study with Swedish public transport frontline staff is described. In the results section, we present illustrations of situations where public transport passengers behave badly and how employees draw on various resources when dealing with these situations. We conclude by summing up the contributions made by our study, as well as its implications for public transport marketing management.

\section{Customer misbehavior}

\subsection{Types of negative customer behaviors}

Several attempts have been made to divide customers' negative behaviors into different categories, e.g. whether verbal or physical, whether directed at people or property, and whether or not it is a matter of a behavior that can be linked to personal financial gain (e.g. pilfering or "gatecrashing" public transport), or whether it is more a case of revenge and retribution (e.g. vandalism and certain forms of violence). Studies in which negative customer behaviors have been divided up and categorized in this and similar ways include Babin and Babin (1996), Fullerton and Punj (2004), Goldstein (1996), Harris and Reynolds (2004), and Lovelock (1994).

In public transport, drivers as well as staff selling and checking tickets are subject to these forms of customer abuse (AFA Försäkring, 2009). Research has shown that customer misbehavior in public transport includes physical violence, verbal threats and abuse, 
drunkenness, the harassment of other passengers, unreasonable demands being placed on staff, and fare evasion (Boyd, 2002; Fellesson et al., 2013; Fullerton and Punj, 2004; Suquet, 2010). A recent study (see Table 1) of 88 transit agencies (U.S. and Canadian transit agencies and a Chinese BRT system) regarding which types of passenger assault have recently been problematic shows that verbal threats, intimidation, or harassment were considered to be the most problematic (TRB, 2011). The second most problematic type of assault was spitting, followed by assaults involving projectiles being thrown at or inside buses.

Table 1

Problematic assault types (TRB, 2011, p. 23)

\begin{tabular}{ll}
\hline Problematic assault types & $\%$ \\
\hline Verbal threats/intimidation/harassment & 81 \\
Assaults involving spitting & 60 \\
Assaults involving projectiles thrown at the buses & 38 \\
Assaults involving projectiles thrown inside the buses (incl. liquids) & 26 \\
Assaults while vehicle is in motion & 9 \\
Assaults due to operator race/gender/size & 5 \\
Simple assaults & 3 \\
Assaults involving weapons & 2 \\
\hline Total number of agency responses (multiple responses were allowed) & 58 \\
\hline
\end{tabular}

Customers "crossing the line" and deliberately violating what is seen as generally accepted norms of conduct is thus far from unknown in the public transport sector. Several statistical sources show that rail and bus operators are facing escalating problems with passengers who threaten and assault both staff and other passengers (AFA Försäkring, 2009; Bruyere and Gillet, 2005; Essenberg, 2003; Kompier and Di Martino, 1995; SEKO and Kommunal, 2005; SWEA, 2008; TRB, 2011). A study of railway and metro frontline staff in Sweden demonstrates that nearly half of them had reported being threatened by passengers during the preceding year (Novus Opinion, 2009). Further, the Swedish work environment agency (SWEA) has reported that nearly half of all reported work-related injuries in public transport were related to violence, or threats of violence, between 2005 and 2007 (Strandberg et al., 2008). In the West Midlands region of the UK, approximately 5\% of all violent crime offences $(12,059)$ committed between 2003/04 and 2005/06 were identified as being associated with public transport (Burrell, 2007). Sixty percent of these offences involved violence against a person, $6 \%$ involved sexual offences, and 34\% involved robbery. A recent report by the Rail Safety and Standards Board in the UK (RSSB, 2011) shows that the second largest contributor (21\%) to fatalities, injuries, and shock and trauma (termed FWI, fatalities 
and weighted injuries) among on-board train crew between 2001/2002 and 2010/2011 was assault and abuse by customers. The same report states that $9 \%$ of all workforce risk (facing staff working at stations, on trains, and on tracks and trackside) is due to assault and abuse. Of these $9 \%, 52 \%$ are related to work onboard trains (crew and drivers). Table 2 illustrates the high frequency of threats and/or violence by customers in different forms of public transport in Canada, UK and Sweden.

Table 2

Frequency of threats and/or violence in public transport

\begin{tabular}{|c|c|c|c|c|c|}
\hline Transport & Customer behavior & Rate & Country & Method & Study \\
\hline$\overline{\text { Bus }}$ & $\begin{array}{l}\text { Verbal assault } \\
\text { Physical assault }\end{array}$ & $\begin{array}{l}55 \% \\
36 \%\end{array}$ & Canada & $\begin{array}{l}\text { Surveys } \\
(\mathrm{N}=1468)\end{array}$ & $\begin{array}{l}\text { Bruyere and } \\
\text { Gillet (2005) }\end{array}$ \\
\hline $\begin{array}{l}\text { Airline } \\
\text { and railroad }\end{array}$ & $\begin{array}{l}\text { Verbal abuse at least once } \\
\text { a month } \\
\text { Physical violence at least once } \\
\text { Physical violence at least twice }\end{array}$ & $\begin{array}{l}74 \% \\
60 \% \\
37 \%\end{array}$ & UK & $\begin{array}{l}\text { Surveys } \\
(\mathrm{N}=252)\end{array}$ & Boyd (2002) \\
\hline Bus & $\begin{array}{l}\text { Verbal threats last } 12 \text { months } \\
\text { Physical violence last } 12 \\
\text { months }\end{array}$ & $\begin{array}{l}29 \% \\
8 \%\end{array}$ & Sweden & $\begin{array}{l}\text { Surveys } \\
(\mathrm{N}=1801)\end{array}$ & $\begin{array}{l}\text { Kommunal } \\
\text { (2008) }\end{array}$ \\
\hline $\begin{array}{l}\text { Railway and } \\
\text { metro }\end{array}$ & Verbal threats last 12 months & $47 \%$ & Sweden & $\begin{array}{l}\text { Surveys } \\
(\mathrm{N}=2000)\end{array}$ & $\begin{array}{l}\text { Novus Opinion } \\
\text { (2009) }\end{array}$ \\
\hline $\begin{array}{l}\text { Railway, } \\
\text { metro } \\
\text { bus }\end{array}$ & $\begin{array}{l}\text { Verbal threats last } 12 \text { months } \\
\text { Physical violence last } 12 \\
\text { months }\end{array}$ & $\begin{array}{l}28 \% \\
10 \%\end{array}$ & $\begin{array}{l}\text { Sweden } \\
(\mathrm{N}=2500)\end{array}$ & Surveys & $\begin{array}{l}\text { SEKO and } \\
\text { Kommunal } \\
\text { (2005) }\end{array}$ \\
\hline $\begin{array}{l}\text { Bus and } \\
\text { taxi }\end{array}$ & $\begin{array}{l}\text { Verbal threats and physical } \\
\text { violence last } 12 \text { months } \\
\text { towards male }\end{array}$ & $18 \%$ & Sweden & $\begin{array}{l}\text { Surveys } \\
(\mathrm{N}=12500)\end{array}$ & SWEA (2008) \\
\hline
\end{tabular}

The table confirms that serious instances of traveler misbehavior are common. It should be noted that the Swedish studies referred to uses the more restricted definition of explicit verbal threats, as compared to the other studies (and the TRB survey reported above) where verbal assaults also include abusive language and insults.

\subsection{Strategies for dealing with negative customer behaviors}

Although still limited, previous research has shown that employees develop and utilize different strategies in order to deal with customer misbehavior. Based on qualitative and quantitative data, Bailey and McCollough (2000) reveal a number of strategies that include employees managing their emotions, compensating and punishing customers, expediting 
(getting it over with as soon as possible), avoiding customers, venting feelings, and referral (e.g. calling a manager). In an interview study of bar, hotel, and restaurant staff, Reynolds and Harris (2006) identify a range of strategies used before, during, and after incidents involving customers who behave badly. These involve everything from keeping an eye out for "warning signals" from customers and using calming language to play on feelings and look for the support of colleagues and other customers. More specifically, Reynolds and Harris (2006, p. 100) uncover the fact that pre-incident strategies among frontline employees include mentally preparing for work, changing their clothing, observing patrons, and consuming drugs. During incidents, strategies used to deal with misbehaving customers include ignoring difficult customers, bribing customers, using emotional labor (e.g. faking sincerity and politeness), exploiting sexual attractiveness, eliciting the support of patrons, altering personal speech patterns, and manipulating the service environment (e.g. removing ashtrays or glasses). Finally, post-incident strategies consist of temporary isolation from others, talking to colleagues, the physical release of emotions, and exacting revenge (e.g. sneezing deliberately on a customer's food before serving it). Acting behind customers' backs or 'getting back' at them as a coping strategy has been registered by other researchers. Noon and Blyton (1997) found that service staff at Disneyland sometimes separated couples or tightened safety belts too hard. Other researchers have shown that the strategies staff use are based on practical assessments which are made during the situations arising (Echeverri et al., 2012). These practical assessments are often grounded in the "silent" knowledge that staff possess, i.e. knowledge which is based on experience and which is difficult to convey via formal training. In a review of research into customer aggression and sexual harassment in service contexts, Yagil (2008) summarizes three types of coping strategies: i.e. problem-solving, escapeavoidance, and support-seeking. When using problem-solving strategies, employees reduce stress by planning and analyzing and by efforts such as observing customers, bribing them, or bending organizational rules. Escape-avoidance includes efforts aimed at disengaging from the problem. Examples include the use of alcohol or cigarettes, avoidance, denial and emotional distancing. Finally, support-seeking strategies include seeking instrumental help, advice or contact, e.g. asking colleagues to cover or venting feelings to them.

When it comes to the effects of these strategies, Yagil (2008) further points out that many of the strategies observed entail the negative behavior being regarded as a part of the job which the staff are forced to accept. In such situations, the employees' strategies not only focus on coping with the problem itself, but also on coping with the emotional distress (Ben-Zur and 
Yagil, 2005; Goussinski, 2012). Emotional labor, as a conscious attempt at managing emotions, is frequent among frontline employees, as Bailey and McCollough (2000) reveal. Such strategies, although successful in the short run, are likely to have negative long-term effects, e.g. psychosocial problems like stress and burnout (see Bishop and Hoel 2008; Hochschild 1983).

\section{Method}

In order to investigate the nature of negative situations in public transport, and the practical strategies used by public transport staff when dealing with such incidents, a qualitative study consisting of 23 in-depth interviews was conducted both with conductors on regional trains and bus drivers on local buses in Sweden (see Table 3). They were all in day-to-day contact with customers and the selection of respondents also ensured a range of ages, experience, and genders.

Table 3

Respondents in the study

\begin{tabular}{llllll}
\hline & $\mathrm{n}$ & Age & Work experience $^{\mathrm{a}}$ & Region $^{\mathrm{b}}$ & Interviews $^{\mathrm{c}}$ \\
\hline Total sample & 23 & $23-60(\bar{x}=38)$ & $1-33(\bar{x}=12)$ & $\begin{array}{l}\mathrm{N}=3, \mathrm{St}=3 \\
\mathrm{~W}=7, \mathrm{~S}=10\end{array}$ & 30 \\
\hline Train (all) & 18 & $23-53(\bar{x}=35)$ & $1-33(\bar{x}=10)$ & $\begin{array}{l}\mathrm{N}=2, \mathrm{St}=1, \\
\mathrm{~W}=6, \mathrm{~S}=9\end{array}$ & 23 \\
Male & 8 & $25-53(\bar{x}=36)$ & $1-33(\bar{x}=13)$ & & \\
Female & 10 & $23-51(\bar{x}=33)$ & $1-18(\bar{x}=7)$ & & \\
\hline Bus (all) & 5 & $44-60(\bar{x}=50)$ & $9-26(\bar{x}=19)$ & $\mathrm{N}=1, \mathrm{St}=2$, & 7 \\
Male & 4 & $44-60(\bar{x}=50)$ & $16-26(\bar{x}=21)$ & $\mathrm{W}=1, \mathrm{~S}=1$ & \\
Female & 1 & 50 & 9 & & \\
\hline
\end{tabular}

${ }^{a}$ Years

${ }^{\mathrm{b}} \mathrm{N}=$ Northern Sweden, $\mathrm{St}=$ Stockholm, W=Western Sweden, $\mathrm{S}=$ Southern Sweden

${ }^{\mathrm{c}}$ Hours

The interviews were conducted by phone and took approx. 45-60 minutes on average. They were recorded in their entirety following approval by those involved. The qualitative approach of open-ended questions enabled flexibility during the interviews and allowed a deeper understanding of how these employees experience and respond to customer misbehavior (cf. Miles and Huberman, 1994). During the interviews, there was a special focus on what happens before, during, and after interactions with difficult customers. Among other things, 
we asked questions about how customers misbehave, how often this was experienced, how as members of staff they acted in these situations, and what resulted from the situation. The interviews were transcribed and then coded using the qualitative analysis program "NVivo".

During the analysis, instances of customer misbehavior were identified and illustrated, as were the employees' strategies for dealing with the situation. The latter were then inductively coded according to how the employees dealt with the situation, inductively leading to three main categories reflecting the resources drawn upon in the strategies. This latter part of the analytical work was inspired by the suggested procedures for analyzing qualitative data associated with grounded theory (Strauss and Corbin, 1998).

\section{Results and discussion}

In this section, we present the results of our empirical study of customer misbehavior in Sweden's public transport sector. We start by accounting for the nature and frequency of the customer misbehavior incidents reported by our respondents. This is followed by a presentation of the strategies used by staff when dealing with negative customer behaviors.

\subsection{Type and frequency of customer misbehavior}

The study qualitatively supports the statistics reported on earlier about misbehaving customers not being uncommon in public transport. All the respondents were able, seemingly with no effort, to recall a number of incidents. One train conductor described the frequent problem of misbehaving customers:

You see, if we talk about chucking them off the train, then maybe it's once or twice a month, maybe. If we talk about calling the police, then maybe it's once a year. If we talk about disputes regarding tickets, incorrect cards and stuff, then it's every single day. (Male train conductor)

The quote shows that the problem of travelers misbehaving is not just about serious incidents like threats and violence, it is also about more run-of-the mill situations. Many of these difficult day-to-day situations arise in conjunction with ticket checks. Some travelers act 
abusively or threateningly when asked to show their tickets and ID. For example, this can be a matter of not having a ticket and not intending to buy one either, that they do not want to show their ID, or that they become unpleasant when they cannot pay by credit card. It is also the case that travelers have forged travel cards and ID documents. Problems can also arise when someone has to be ejected from a train. A common form of negative customer misbehavior is verbal abuse. The staff interviewed say that it is often the case that abuse is linked to the appearance, age, origin, and gender of staff. Junior staff seem to be affected more frequently, especially women. Some examples of verbal abuse by travelers include the following:

Then there was one traveler, dressed for business in a shirt and tie and all that, who didn't have a ticket and we don't take cards so yes, then he got irritated about that. Then he looks at her [the conductor] and says: "When you're so fat and ugly, why are you doing this job?" (Male train conductor)

You get called things regardless of whether you're Swedish or a foreigner working on the train. My colleague was called a "bloody racist!" or they call me a "bloody immigrant!" - so you get to hear unpleasant and threatening words. (Female train conductor) Lots of young women get insulted. They get called one thing and another, like "little girl and missy" and "you little shit, telling someone like me who's a lot older". (Male train conductor)

The first quote illustrates how insulting comments about appearance are used to call into question why the staff member is working in that job. The study indicates that it is more common for women to be exposed to comments about appearance and also, as the third quote illustrates, to comments relating to age and gender. Some insults also escalate into pure threats. A train conductor stated the following:

So I managed to throw myself into the driver's cab, and then he [the customer] screams that he's going to murder me and the driver. And we managed to shut the door and lock it, and then we had to wait for the police to arrive and he just stood there the whole time screaming that he was going to commit murder. [...] I 
haven't been physically assaulted, but I have been threatened with murder and chased. (Female train conductor)

There are also examples of staff being chased on their way home after ejecting travelers from trains. Several stories deal with violence, ranging from more "minor" types to needing hospital treatment:

Yes, a common example today is being spat at in the face. And that's immediately classified as violence, we've found out ... it's rather common. (...) and it's quite common to be shoved, shoved into the vestibule, where you stand waiting to get off. (Male train conductor)

I know a colleague, just a few weeks ago, he chucked a traveler off his train. And when he was just about to depart, he was jumped from behind and the traveler twisted his arm up behind his back and was going to push him into the train. And it was completely unexpected as he had his back turned. And then he had to spend time at $A \& E$ and was off sick for a week. (Male train conductor)

Frequently, alcohol and other drugs are involved, but this is far from always the case. The interviewees are also careful to point out that bad behavior cannot always be linked to a specific group, all types of travelers can misbehave. Even apparently "normal" and wellmannered travelers can suddenly behave really badly.

\subsection{Strategies for dealing with negative customer behaviors}

We have identified three categories of strategies that staff use to deal with negative customer behaviors. This is about strategies based on appearance, interaction, and the physical environment.

\subsubsection{Strategies based on appearance}

In a number of cases, the employees' body posture, gestures, and aesthetic appearance were effectively used to deal with deviant customers. These qualities also had a preventive and deterrent effect as the physical appearance of staff, e.g. tattoos or body size, decreased the 
occurrence of misbehavior. One employee described how his appearance influences how people engage with him:

I'm shaven and tattooed, so I don't get the problems that some others do. Cause they look at me but they don't know exactly what to make of me. If people want to fight, then they want, yeah people want to have the upper hand and they won't get that against me (...) I really believe that I dodge lots of trouble by looking the way I do. (Male train conductor)

Often, appearance is about either strengthening the position of power vis-à-vis the customer or, on the contrary, toning it down. The uniform that train crew wear is perceived to be provocative by certain travelers, and then it can be important not to strengthen the position of power any further. One employee describes this thus:

I'm standing, of course, and that's immediately a position of power as I have a uniform too. Bear in mind never to stand in such a way that you really ... actually oppress people even more. But think about, what you give off in terms of how you're standing relative to the traveler. (Female train conductor)

Other results also indicate that appearance can be a disadvantage. For example, young female employees tend to be hit by problems more frequently due to gender and size, additionally finding it more difficult to deal with things. A young woman describes how she sometimes feels the customer has the upper hand:

Because this guy, it wasn't a youngster who was refusing to pay but a mature man! And then ... you see, I'm rather small and slender, and the fact that a woman comes looking for your ticket ... (Female train conductor)

The results indicate that employees use their appearance in a number of ways to deal with misbehaving customers. Some of these strategies are easier to adapt to individual situations than others. The employee's body posture and gestures are examples of the former, while body size, tattoos and clothing, in the guise of uniforms, represent more stable characteristics of appearance. 


\subsubsection{Strategies based on interaction}

Employees' verbal skills were also important when dealing with and preventing customer misbehavior. In this regard, numerous strategies were used, e.g. letting the customer talk, acting calm, keeping a friendly tone, and establishing trust. A heated discussion can, for instance, be toned down simply by means of the employee showing that he/she is actively listening to the customer. One employee describes how he allows travelers to finish speaking or "get it off their chests":

You don't need to get bogged down in their discussion, you can be slightly cold. And let them finish what they want to say. If they're standing there shouting, you can ask them to quieten down a bit, but let them talk anyway. That's the most important bit, that's the most important bit of the case, that you're showing that you're sensitive. (Male train conductor)

Several respondents talk about the need for a light touch, balancing things and being able to act "smart" when interacting with the troublesome traveler:

In order to attempt to get things in balance, as I usually call it, you need a good knowledge of people, most of the time. You must be able to deal with the case in a balanced way, you must be able to judge "Is this worth it?”, "What will happen?”, "What exactly are my guidelines for doing this?" [...] "How will this turn out, where is the person going?" (Male train conductor)

Other interactional strategies involve ignoring the customer or acting authoritatively. An example of this is the following description:

Instead of bickering with them, I usually just ignore them, turning round and just saying "Yes, but that's the end of it" and then I walk away. And that usually works quite well, actually. (Female train conductor)

Many employees also choose to avoid "sensitive" words (e.g. fines, penalty fares) as they know, from experience, that these can start the customers off. One employee says: 
I've learnt, for instance, never to say "I'll call the police". That was something which you did at the beginning and which they also taught you to do previously, that this was a good thing to say as it usually calmed people down. But it's more like the opposite. I never say that when I need to call the police, instead the police are there all of a sudden and that's a whole lot better. (Female train conductor)

The employee has been instructed to say that the police will be called, but he had also noticed, from his own experience, that this was more likely to inflame travelers than to calm them. The quote above also reflects the difficulty of issuing and teaching general methods of acting when it comes to this type of incident. Being able to "handle people" is very much about experience and being able to interpret and act in each specific situation. What is right in one situation for a specific employee will not always work for another employee in a different situation.

Sometimes, the employees also choose to abandon formal rules and, for example, allow a customer to travel without paying in order to avoid a conflict. One employee says:

I might have helped myself out a few times by preferring to back down rather than challenge fate. If I feel that this is a person who could get threatening, then I won't charge him a penalty fare cause I don't think my life is worth damaging for the sake of that fare and I might let that person stay on the train instead. (Female train conductor)

Over and above that, staff also make use of other travelers as an "audience" to get a difficult customer to calm down by exposing that troublesome traveler to psychological group pressure. Several of those we interviewed raise, in this context, the problem of travelers who try to travel in first class despite not having paid for it. One employee exemplifies how he talks to a customer in a slightly louder voice so that the others in the compartment also hear:

[Talking to the customer] "You'll just have to respect that - as you can see the others sitting here - they've actually paid more than you. Why should you be allowed to stay here?" Then, you enlist the help of the others in some way, that's a bit psychological too, 
as you've learnt. Then he feels; "Well, the others will be looking at me in a horrible way if I stay here". (Female train conductor)

Another interactional tactic involves staff sometimes deliberately lying to customers. In one case we were told about, the customer had no ticket and did not intend to pay for one either. The employee then said he would turn a blind eye if the customer left the train at the next station. The employee then called the police, who apprehended the customer at the station.

\subsubsection{Strategies based on the physical environment}

In addition to the individual's appearance and interactional skills, several strategies also related to the physical environment and the employee's physical location in relation to a aberrant customer. The physical environment is perceived, in many cases, as a limitation since train crews and bus drivers have few possibilities of avoiding abusive or threatening travelers. The physical environment was also utilized, however, in preventive strategies. Examples of such strategies include planning ahead by keeping track of time and train stations in order to be able to eject aberrant customers, informing the police about the specific train door where the customer is going to get off, waiting before opening the doors at a station so that the police can get into position, scanning the compartment for potential misbehavior. The respondents tell, for example, of creative strategies whereby they might seat a troublesome traveler in an empty compartment or turn up the heating in a compartment in order to send drunken travelers to sleep. One employee described this:

\section{Personally, I turn up the heating to the highest "level", cause then they fall asleep most of the time, if they're drunk that is. I've learnt little tricks, you know! So, at times, if it's really hot in a carriage, then you'll know what that's down to! (Female train conductor)}

Other strategies relating to the physical environment include keeping an appropriate physical distance from the customer, always facing him/her (i.e. not turning your back), and not blocking a customer's way. The staff is of the opinion that their position vis-à-vis the customer is important; for instance, they are reluctant to position themselves between the traveler and the doors or to turn their backs on a threatening traveler. They are aware of how the physical environment looks and they make sure they are correctly positioned in relation to the doors and the traveler. An example of this: 
Well, really, you don't want to be by the doors with the traveler, but if I have to, then I make sure I have eye contact with him and that I'm facing him. So I never stand in such a way that he only sees my back as that can start them off. (Male 25, train conductor)

We also see that the staff not only take into account the spatial aspects but also the temporal ones by avoiding conflicts before the train has reached a station. As it is impossible for them to both obtain help and leave the train while it is moving, they try to synchronize conflict situations in such a way that the train is standing at a station. They allow the traveler to continue to travel without getting into a discussion until arrival. One employee describes how he usually deals with customers who do not want to pay for a ticket:
And you kind of say; "Ok, you're going to Helsingborg and you don't want to pay”. "Nope, I don't want to pay”. "Ok, it's a no then. No, but it's ok, you can go to Helsingborg”. Then you forget about that person. This is also one of my tips; that you pull a fast one. You allow them to travel to a station where you know you can call in external support [police] who can then take over in a completely different way. (Male train conductor)

\begin{abstract}
All in all, although the physical environment often imposes limitations on the employees' possibilities of acting, it was also actively used to deal with, and even prevent, customer misbehavior.
\end{abstract}

\title{
5. Conclusions and implication for managerial practice
}

This study contributes to previous research into misbehaving customers of services. In particular, it also contributes to the normative literature on how to deal with "difficult" customers of services. This literature has tended to focus on how to manage customer and staff behavior, e.g. via routines, instructions, and training schemes. Our study indicates that this might not be enough and that both the physical appearance of staff and the physical service setting might be crucial as regards what actually happens during the "moment of truth'. Further, research into customer misbehavior in public transport is still very limited and most studies are statistical reports made by trade associations or work environment agencies, often using a normative and prescriptive approach. Although important, these studies 
primarily focus on the occurrence of threats and violence in the transport sector and do not distinguish this kind of behavior from other "milder" kinds, such as verbal abuse. Even less is known about how employees in the public transport sector deal with situations where customers cross the line when it comes to what is considered acceptable behavior.

This study has illustrated both the prevalence and the types of customer misbehavior, as well as the strategies used by conductors on regional trains and bus drivers on local buses in Sweden. Different types of verbal abuse are common, especially when targeting young female workers; however, there are also examples of threats and even of violence. None of our respondents had any difficulty at all recounting numerous episodes, both their own and those of colleagues. Particularly remarkable is the fact that so many of these events that the interviewees talk about deal with "ordinary" travelers and that these situations cannot be related to alcohol or narcotics, or to mental illness.

This is an area that should be studied more closely. Why do supposedly well-behaved people misbehave while travelling by public transport? Here, we can envisage explanatory models based on both the situation per se (do these situations arise in connection with critical events?), on public transport systems as such (does the "mass" in mass transit bring out the worst in people?), and on more societal perspectives (can the behavior be related, for instance, to a societal trend in which we are increasingly frequently being expected to act, and see ourselves as sovereign customers)?

When it comes to staff strategies for dealing with situations, our study shows both creativity and competence. The results show the employees' appearance, their interaction with the customers, and their use of the physical environment as three major categories of strategy when dealing with misbehavior. Dealing with troublesome travelers seems to be an important part of a professional, and partly silent, knowledge base. Reference is often made to company routines and guidelines, as well as to different courses which have been attended; however, when the actual practical management of a situation is described, it is instead terms like flexibility and common sense that dominate. In particular, the relationship between practically-functioning strategies and formal policies/guidelines and training efforts is another area that should be further researched. What type of knowledge do staff make use of when dealing with a situation, and how can this knowledge be developed and mediated? 


\subsection{Implications for managerial practice}

Functional, positive encounters between customers and employees is pivotal for organizations. Service encounters are linked to customers' perceptions of service quality and interactions also create opportunities for mutual value creation during which organizations can learn more about their customers' needs. Day-to-day interactions are thus of strategic importance. Situations where customers misbehave entail a risk of negatively affecting other customers' perceptions of services, in addition to constituting a work environment hazard that detrimentally affects employees' long-term motivation and wellbeing. A deeper understanding of these negative situations, and the strategies used by employees, can help to stimulate further market development of the public transport sector.

This study shows three major categories of strategy used by employees. These strategies can form the basis of employee training in public transport organizations. Training in interaction techniques, both verbal and nonverbal, could strengthen employees' abilities to act preventively as well as during ongoing situations involving misbehaving customers. However, as mentioned in the previous section, the relationship between policies and formal training, on the one hand, and the capacity to actually deal with a situation, on the other, might be more complicated than first thought. Many of the respondents seek support in the form of clear instructions and recommendations, but also more training in customer care. Since it is in many situations a matter of skills that are difficult to formalize and "put down on paper", it is also important for staff to be given opportunities for exchanging experience and learning, dayto-day too. This is hampered by the fact that it is a geographically widespread operation with lots of working alone. Thus, there may be a need for special forums for knowledge exchange.

The results of this study can also contribute to other preventive actions when it comes to misbehaving customers. For example, public transport organizations may need to reflect upon their policies regarding employee uniforms, and how the design of vehicles and facilities either enables employees to act or prevents them from doing so during these situations. Several employees stated that their uniforms seemed to intimidate some customers, especially during ticket inspections. The environment influences the way employees position themselves when interacting with the customers, their ability to move around (e.g. within a carriage), and their ability to communicate with others both inside (e.g. colleagues or management) and outside (e.g. police or security staff) the organization. 
This implies that managers need to broaden their horizons and look beyond the individual situation and the individual customer's traits when seeking the causes of and remedies for misbehavior. As previous research findings indicate, systematic shortcomings in the service system design can trigger misbehavior (Fellesson et al., 2013). We feel that there should be good opportunities for working preventively by means of systematically analyzing and coordinating the operation's various subsystems, and by means of highlighting the frequently complex causal links that exist within a transport system. Not least, the relationship between demands regarding control and service is something that needs to be investigated more closely, e.g. by being juxtaposed against technical and organizational conditions, but also, as pointed out above, against both the customer role and the expectations associated with being a customer of public transport.

\section{References}

AFA Försäkring (2009). Allvarliga arbetsskador och långvarig sjukfrånvaro. [Serious workrelated injuries and long-time sick leave] Stockholm: AFA Försäkring.

Babin, B. J., \& Babin, L. A. (1996). Effects of Moral Cognitions and Consumer Emotions on Shoplifting Intention. Psychology and Marketing, 13(8), 785-802.

Bailey, J. J., \& McCollough, M. (2000). Emotional labor and the difficult customer: coping strategies of service agents and organizational consequences. Journal of Professional Services Marketing, 20(2), 51-72.

Bendapudi, N., \& Bendapudi, V. (2005). Creating the living brand. Harvard Business Review, May, 83(5), 124-132.

Ben-Zur, H., \& Yagil, D. (2005). The relationship between empowerment, aggressive behaviors of customers, coping and burnout. European Journal of Work and Organizational Psychology, 14(1), 81-99.

Berry, L. L. \& Seiders, K. (2008). Serving unfair customers. Business Horizons, 51(2), 29-37.

Bishop, V., \& Hoel. H. (2008). The Customer is Always Right?: Exploring the concept of customer Bullying in the British Employment Service. Journal of Consumer Culture, 8(3), 341-367. 
Bitner, M. J., Booms, B. H., \& Mohr, L. A. (1994). Critical service encounters: the employee's viewpoint. Journal of Marketing, 58, 95-106.

Bowen, D. E, \& Schneider, B. (1988). Services marketing and management: Implications for organizational behavior. Research in Organizational Behavior, 10, 43-80.

Boyd, C. (2002). Customer violence and employee health and safety. Work, Employment and Society, 16, 151-169.

Bruyere, D., \& Gillet, J.M. (2005). National Operator Assault Survey Results 2005. Mississauga, Ontario, Canada: ATU Transit Operators.

Burrell, A. (2007). Violence on and around public transport. JDI Crime Science Laboratory, UK. Available at: http://www.ucl.ac.uk/scs/downloads/research-reports/violence-publictransport [accessed October 6, 2013].

Dormann, C., \& Zapf, D. (2004). Customer-related social stressors and burnout. Journal of Occupational, Health Psychology, 9(1), 61-82.

Echeverri, P., Salomonson, N., \& Åberg, A. (2012). Dealing with customer misbehaviour: employees' tactics, practical judgement and implicit knowledge. Marketing Theory, 12(4), 427-449.

Essenberg, B. (2003). Violence and stress at work in the transport sector. Working Paper No. 205, ILO Publications, Geneva: International Labour Office.

Fellesson, M., Salomonson, N., \& Åberg, A. (2013). Troublesome Travelers - The Service System as a Trigger of Customer Misbehavior. International Journal of Quality and Service Sciences, 5(3), 256-274.

Fullerton, R. A. \& Punj, G. (1993). Choosing to Misbehave: A Structural Model of Aberrant Consumer Behavior. Advances in Consumer Research, 20(1), 570-574.

Fullerton, R. A., \& Punj, G. (2004). Repercussions of promoting an ideology of consumption: consumer misbehavior. Journal of Business Research, 57(11), 1239-1249.

Goldstein, A.P. (1996). The Psychology of Vandalism. New York: Plenum Press.

Goussinsky, R. (2012). Coping with customer aggression. Journal of Service Management, 23(2), 170-196. 
Grandey, A. A., Dickter, D.N., \& Sin, H. -P. (2004). The customer is not always right: customer aggression and emotion regulation of service employees. Journal of Organizational Behavior, 25(1), 1-22.

Grove, S. J. \& Fisk, R. P. (1997). The impact of other customers on service experiences: a critical incidents examination of 'getting along'. Journal of Retailing, 73(1), 63-85.

Harris, L. C. \& Daunt, K. (2013). Managing customer misbehavior: challenges and strategies. Journal of Services Marketing, 27(4), 281-293.

Harris, L. C. and Reynolds, K. L. (2003). The consequences of dysfunctional customer behavior. Journal of Service Research, 6(2), 144-161.

Harris, L. C. \& Reynolds, K. L. (2004). Jaycustomer Behavior: An Exploration into the Types and Motives in the Hospitality Industry. Journal of Services Marketing, 18(5), 339-357.

Hochschild, A. (1983). The Managed Heart. Commercialization of Human Feeling. Berkeley, CA: University of California Press.

Huang, W. H. (2008). The impact of other-customer failure on service satisfaction. International Journal of Service Industry Management, 19(4), 521-536.

Jones, C., Taylor, G., \& Nickson, D. (1997). Whatever it takes? managing 'empowered' employees and the service encounter in an international hotel chain. Work, Employment \& Society, 11(3), 541 - 554.

Kommunal (2008), Hot och våld i kollektivtrafiken. [Threats and violence in public transport] September, 2008.

Kompier, M. A. J., \& Di Martino, V. (1995). Review of bus drivers' occupational stress and stress prevention. Stress Medicine, 11(1), 253-262.

Korczynski, M., Shire, K., Frenkel, S., \& Tam, M. (2000). Service Work in Consumer Capitalism: Customers, Control and Contradictions. Work, Employment and Society, 14(4), 669-687.

Levitt, T. (1960). Marketing myopia. Harvard Business Review, 38 (July-August), 45-56.

Lovelock, C. H. (1994). Product Plus: How Product and Service = Competitive Advantage. New York: McGraw-Hill. 
Martin, C. L. (1996). Consumer to consumer relationships: satisfaction with other consumers' public behavior. Journal of Consumer Affairs, 30(1), 146-169.

Miles, M. B. \& Huberman, A. M. (1994). Qualitative Data Analysis, Thousand Oaks, CA: Sage.

Molander, S., Fellesson, M., Friman, M., and Skålén. P. (2012). Market orientation in Public transport research - A review. Transport Reviews, 32(2), 155-180.

Noon, M., \& Blyton, P. (1997). The Realities of Work. London: Macmillan.

Novus Opinion (2009), Medlemmar inom spårtrafik om sin arbetsmiljö. På uppdrag av SEKO, [Members of rail trafic about their work environment. On behalf of SEKO] Stockholm.

Pugh, S. D., Dietz, J., Wiley, J. W., \& Brooks, S.M. (2002). Driving Service Effectiveness through Employee-Customer Linkages. The Academy of Management Executive, 16(4), 73 84.

Reynolds K. L. \& Harris, L. C. (2006). Deviant Customer Behavior: An Exploration of Frontline Employee Tactics. Journal Marketing Theory and Practice, 14(2), 95-111.

RSSB (2011). Annual Safety Performance Report 2010/11, London, Available at: http://www.rssb.co.uk/sitecollectiondocuments/pdf/reports/ASPR\%20201011\%20Full\%20Report.pdf [accessed October 20, 2013]

SEKO and Kommunal (2005). Hot och våld. SEKO och Kommunal, [Threats and violence. SEKO and Kommunal] Stockholm.

Strandberg, U., Norrby, U., Melander, D., \& Brink, C. (2008). Våld och hot i kollektivtrafiken. Etapp 1 av Arbetsmiljöverkets särskilda tillsynsinsats riktad till kollektivtrafiken, Rapport 2008:2 [Threats and violence in public transport. Phase 1 of The Swedish Work Environment Authority's supervision of public transport, Report 2008:2]. Stockholm: Arbetsmiljöverket.

Strauss, A., \& Corbin, J. (1998). Basics of Qualitative Research: Techniques and Procedures for Developing Grounded Theory. 2nd ed., Thousand Oaks, CA: Sage.

Sturdy, A. (1998). Customer care in a consumer society: Smiling and sometimes meaning it?. Organization, 5(1), 27-53. 
Suquet, J. (2010). Drawing the line: how inspectors enact deviant behaviors. Journal of Services Marketing, 24(6), pp. 468-475.

SWEA (2008). Arbetsmiljön 2007, Arbetsmiljöstatistik. Rapport 2008:4, Arbetsmiljöverket [The work environment 2007, Work environment statistics. Report 2008:4, The Swedish Work Environment Authority], Stockholm.

TRB (2011). Practices to Protect Bus Operators from Passenger Assault: A Synthesis of Transit Practice. TCRP Synthesis 93, Washington, DC: Transport Research Board..

van Dierendonck, D., \& Mevissen, N. (2002). Aggressive behavior of passengers, conflict management behavior, and burnout among trolley car drivers. International Journal of Stress Management, 9(4), 345-355.

Yagil, D. (2008). When the customer is wrong: a review of research on aggression and sexual harassment in service encounters. Aggression and Violent Behavior, 13(2), 141-152. 